\title{
NUTRITIONAL STUDIES ON PROMISING PLANTS FOR NEPHROPATHY TREATMENT OF MALE ALBINO RATS.
}

\author{
By \\ Prof. Dr. Fatma El-Zahraa Amin \\ Prof. Dr. Ayman El-Sayed El-Adawy \\ Professor of Nutrition and Food \\ Professor of Nutrition and Food \\ Science, Ex.Dean Faculty of Home \\ Economics, Minufiya University \\ Science, Faculty of Home Economics, \\ Minufiya University \\ Dr. El-Sayed Hamed Ali Bakr \\ Lecturer of Nutrition \\ and Food Science, Faculty of Home \\ Economics, Minufiya University \\ Ebtisam Mohammad Ali Aldafrawy \\ Dietitian Fever Hospital Damanhur
}

Research Gournal Specific Fducation

Faculty of Specific Fducation

Mansoura University

ISSUE NO. 32, OCTOBER. 2013

$$
\begin{aligned}
& \text { مجلة بحوث التربية النوعية ـ جامعة المنصورة }
\end{aligned}
$$

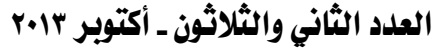




\section{NUTRITIONAL STUDIES ON PROMISING PLANTS FOR NEPHROPATHY TREATMENT OF MALE ALBINO RATS.}

Prof. Dr. Fatma El-Zahraa Amin * Prof. Dr. Ayman El-Adawy ${ }^{*}$

Dr. El-Sayed Hamed Ali Bakr ${ }^{* * *}$ Ebtisam Mohammad Ali

\section{ABSTRACT}

The present work aimed to evaluate the effect of Almond nut, Sambucus herbs, Juniperus seeds, Grapefruit albedo \& the combination of all(as $5 \%)$ on reinopathic rats. For this purpose , the study included about 35 rats about 150/200(g) weight. Biological \& chemical analysis of serum and histopathological investigation of internal organs were carried out. The experiment lasted for 4 weeks and eventually urine samples were collected for each rat for 24 hours and size measwredand estimated (creatinine - urea - uric acid - protein - sodium - potassium). The weight of the rats and collect blood samples after collected fasting 12 hours and then serum separated to estimation of (creatinine - urea - uric acid - lipid profile - sodium potassium - GPT-ALP-GOT). The weight of the internal organs (liver kidney - heart - spleen - lung) determined and fixed in $10 \%$ formalin for histopathological examinations. finally a statistical analysis of all the data and was done.

\section{INTRODUCTION}

Chen et al.,(2006)claimed that almond provides with a nutrient-dense source of vitamin E, manganese, magnesium, copper, phosphorus, fibre, riboflavin, monounsaturated fatty acids and protein. Although almost 50\% of almond weight is fat, incremental intakes of $7 \mathrm{~g} /$ day of this tree nut

\footnotetext{
* Professor of Nutrition and Food Science, Ex.Dean Faculty of Home Economics, Minufiya University

Professor of Nutrition and Food Science, Faculty of Home Economics, Minufiya University

Lecturer of Nutrition and Food Science, Faculty of Home Economics, Minufiya University

Dietitian Fever Hospital Damanhur
} 
reduced low-density lipoprotein (LDL) cholesterol concentration by $1 \%$, especially within the context of diets recommended by the National Cholesterol Education Program. Habitual almond consumption does not lead to weight gain, and their inclusion in low-calorie diets appears to promote more weight loss than a comparable carbohydrate-based lowcalorie diet. Also, almonds have a low glycemic index and do not adversely impact insulin sensitivity. Almonds are an excellent source of bioavailable $\alpha$-tocopherol,

Gray et al.,(2000) announced that Sambucus nigra (elder) has been documented as a traditional treatment of diabetes.. The results, demonstrated the presence of insulin-releasing and insulin-like activity in the traditional antidiabetic plant, Sambucus nigra.

Khan et al.,(2012) said that Juniperus excelsa Bieb. is used in folk medicine for lowering blood pressure (BP). Its BP-lowering effect, endothelium-dependent and endothelium-independent vasodilator effects, and cardio-modulatory effect was stadied. The crude extract of J. excelsa (Je.Cr) induced a dose-dependent $(10-300 \mathrm{mg} / \mathrm{kg})$ fall in the arterial BP of anesthetized rats. In isolated rabbit aorta, Je.Cr $(0.01-5.0 \mathrm{mg} / \mathrm{mL})$ inhibited high $\mathrm{K}(+)(80 \mathrm{mM})$ - and phenylephrine $(1 \mu \mathrm{M})$-induced contractions, like that caused by verapamil and papaverine. In guinea pig atria, Je.Cr initially caused mild cardiac stimulation, followed by inhibition, like that exhibited by papaverine. These results reveal that cardiovascular effects of J. excelsa are mediated possibly through a combination of $\mathrm{Ca}(++)$ antagonism, nitric oxide-modulating mechanism, and phosphodiesterase inhibitory mechanism, which explain its medicinal use in hypertension.

Fellers et al.,(1990) reported that Grapefruit is an excellent source of many nutrients and phytochemicals that contribute to a healthy diet. Grapefruit is a good source of vitamin C, contains the fiber pectin, and the pink and red hues contain the beneficial antioxidant lycopene. Studies have shown grapefruit helps lower cholesterol, and there is evidence that the seeds have antioxidant properties. Grapefruit forms a core part of the "grapefruit diet", which was with low glycemic index ,being able to help the body's 
$\overline{\underline{ }}$

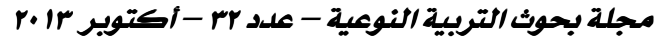

metabolism burn fat. The grapefruit albedo needs to be investigated for amelioration of nephropathy. The same conld be suggested for almond nut, elder and Juniperus excelsa.

\section{MATERIALS AND METHODS}

\section{1- The used plants and their preparation:}

The plants used in this study were:

- Almond nut (Prunus dulcis)

- Sambucus herbs(SP.L.)

- Juniperus seeds (SP.L.)

- Grapefruit albedo (Citrus paradise)

The plants ,nuts\&grapefruit obtained from supermarket and the special shop and then dried, milled and added to diet.

\section{"Biological experiment"}

\section{2-Basal diet composition of tested rats:}

The basal diet consisted of casein (12\%), corn oil (10\%), choline chloride $(0.25 \%)$, vitamin mixture (1\%), cellulose $(5 \%)$, corn starch (up to $100 \%$ ) and salt mixture (4\%), according to (Campbell, 1963), and the composition of salt and vitamin mixture were according to (Hegested et al., 1941 and Campbell, 1963).

\section{3-Preparation of Rats with Impaired Kidney:}

Impaired kidney conld be induced in normal healthy male albino rats by intra-peritoneal injection of gentamicin(aminoglycosides antibiotics) obtained by Memphis Co. form Pharm .Chem.Itd.Cairo.A.R.E.at 10 $\mathrm{mg} / \mathrm{kg} /$ day for 6days in which the nephrotoxicity,one of the adverse reaction of gentamicin takes place.

\section{4-Experimental design and animal groups:}

Thirty five (35) adult male albino rats, Sprague - Dawley strain, weighting $(150 \pm 10 \mathrm{~g})$ were used. All rats were fed on basal standard diet for seven consecutive days as adaptation period. Then, rats were distributed into 7 groups each of 5 rats in which means of rats weight for all groups 
were nearly equal. All the groups of rats were housed in wire cages and fed on the experimental diet for 4 weeks according to the following groups:

- Group (1): This group was fed on basal diet only as a negative control (healthy rats) (c-ve) $(n=5)$.

- Group (2): This group was fed on basal diet only as a positive control (rats with impaired kidney by gentamicin) (c+ve) $(n=5)$.

- Group (3): This nephritis group was fed on basal diet containing 5\% Almond nut.

- Group (4): This nephritis group was fed on basal diet containing 5\% Sambucus herbs.

- Group (5): This nephritis group was fed on basal diet containing 5\% Juniperus seeds.

- Group (6): This nephritis group was fed on basal diet containing 5\% Grapefruit albedo.

- Group (7): This nephropathy group was fed on basal diet containing $5 \%$ mixture of plants powder

\section{5-Biological evaluation:}

During the experimental period (28days), the diet consumed recorded every day, and body weigh recorded every week. The body weight gain (BWG g), feed efficiency ratio (FER), and also organs weights determinated according to Chapman et al., (1959).

\section{6-Urine and serum:}

At the end of experiment period, the urine of each rats was collected for 24 hours and it was analyzed for determination the following parametera: Total protein, sodium and potassium.

Also, blood samples were collected after 12 hours fasting at the end of experiment in which the rats were scarified under ether anesthsia. Blood samples were received into clean dry centrifuge tubes and left to clot at room temperature, then centrifuged for 10 minutes at $3000 \mathrm{rpm}$ to separate the serum. Serum was carefully aspirated and transferred into clean cuvette tubes and stored frozen at $20^{\circ} \mathrm{Cfor}$ analysis. All serum samples were analyzed for determination of following parameters: urea, uric acid , 
$\overline{\underline{ }}$

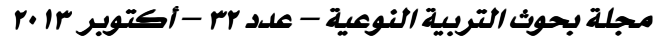

creatinine, sodium \& potassium, gluatmic oxaloacetic transaminase (GOT), and glutamic pyruvic transaminase (GOT), alkaline phosphatase (ALP) proiten , total cholesterol, triglycerides, high density lipoprotein and glucose.

At the same time the organs: Heart. kidney, lungs, liver, and spleen were removed ,cleaned, weighted, and stored frozen in formallin solution $10 \%$ for histopathological testing according to method mentioned by Drury and wallington(1980).

\section{7-Analytical Methods:}

\section{.Determination of urea:}

Urea was determination was according to the enzymatic method of Patton and Crouch(1977).

\section{.Determination of uric acid:}

Uric acid was determination according to the enzymatic Colorimetric test of Fossatti and prencipe (1980).

\section{.Determination of creatinine:}

Creatinine was determinaed according to kinetic method of Henry (1974).

.Determination of serum glutamic oxaloacetic transaminases (GOT) and glutamic pyruvic transaminase (GPT) alkaline phosphatase (ALP),total protein:

GOT and GPT activities were measured according to method described by Thefeld(1974) while determination of total protin according to the colorimetric method of Henry(1964).

\section{.Determination of sodium:}

Sodium was measured according to the colorimetric method of Henry (1974).

\section{.Determination of Potassium:}

Potassium was measured according to the colorimetric method of Henry (1964). 


\section{.Determination of serum lipid:}

\section{1-Triglcerides}

Enzeymatic colorimtric determination of triglycerides was carried out accolrding to Fossati and Prencipe (1980)

\section{2- Total cholesterol:}

Total cholesterol was determined by colorimetric method accolrding to NIHP(1984).

\section{3-HDL-cholesterol:}

Determination of HDL was carried out according to the method of Fnedewaid (1972) and Gordon and Amer(1977).

\section{4-VLDL\&LDL-cholesterol:}

The determination of VLDL (very low density lipoproteins) and LDL (low density lipoproteins)were carried out according to the methold of Lee and Nieman (1996) by calculatioln as follows:

$*$ VLDL $(\mathrm{mg} / \mathrm{dl})=$ Triglycerides $/ 5$

*LDL $(\mathrm{mg} / \mathrm{dl})=$ Total cholesterol $-\mathrm{HDL}-\mathrm{VLDL}$

\section{5-Determinatioln of atherogenic index (AI):}

Atherogenic index was calculated according to Nakabayashi et al .,(1995) as follows:

$$
\text { Atherogenic index }(\mathrm{AI})=\frac{\boldsymbol{L D L}+\boldsymbol{V} \boldsymbol{L D L}}{\boldsymbol{H D L}}
$$

\section{8-Statistical analysis}

The obtained data were statistically analyzed using computerized SSPS (Statistic Program Sigmastat, Sataistical Soft- Ware, SAS Institute, Cry, NC ). Effects of different treatments were analyzed by one way ANOVA (Analysis of variance ) test using Duncan's multiple range test and (Snedecor and Cohran, 1967). 
$\overline{\underline{ }}$

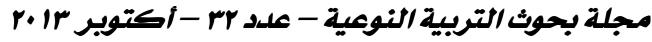

\section{9- Histopathological examination :}

At end of the examination which continued for 28 successive days, all rats were sacrificed, organs including liver, kidney and heart were taken for histopathological examination according to Drury and Wallington (1980).

\section{RESULTS AND DISCUSSION}

A-Effect of almond nut, Sambucus herbs, Juniperus seeds, Grapefruit albedo \& the combination of all on body weight gain(BWG), feed intake(FI) $\&$ feed efficiency ratio(FER) of reinopathic rats.

\section{Body weight gain $(B W G) g / 28$ days;}

Table(1) show the mean value of body weight gain (BWG/28days) of reinopathic rats fed on various diets. It could be noticed that the mean value of $\mathrm{BWGg} / 28$ days of control (+) group was lower than control (-) group, being $6.20 \pm 0.68 \& 10.78 \pm 0.27$ respectively, showing significant difference with percent of increase $+73.87 \%$ as compared to control (+).All reinopathic rats fed on various diets showed significant increases in mean values as compared to control (+) group. The best BWG was recorded for group 3 (reinopathic rats fed on almond seeds) when compared to control (+) group.

\section{Feed intake (F.I):}

Table(2) results indicates the mean value of feed intake (g/day) of reinopathic rats fed on variable diets. Data revealed that the mean value of( FI) of control (+) group was higher than control (-) group,being15.18 \pm 0.75 \& $12.28 \pm 0.63 \mathrm{~g}$. respectively. All reinopathic rats fed on various diets showed significant decreases in mean values as compared to control $(+)$ group. Rats fed on groups 3,4,5,6\&7 showed nonsignificant differences between them. Numerically the best FI was recorded for group7 (reinopathic rats fed on mixture of all plants) when compared to control (-) group.

\section{Feed efficiency ratio(FER).}

Table(3) results illustrate the mean value of FER of reinopathic rats fed on different diets. Data show that the mean value of FER of control $(+)$ group was lower than control (-) group,being0.015 $\pm 0.002 \& 0.031 \pm 0.003$ respectively,indicating significant difference. All reinopathic rats fed on 
various diets showed significant increases in mean values as compared to control (+) group . Rats fed on groups 3,4,5,6\&7 showed nonsignificant differences between them . Numerically the best FER was recorded for group $3 \& 4$ (reinopathic rats fed on almond nut,sambucus herbs).

The obtained results are in line with that of Sheir,Marwa(2009). Wien et al.,(2003);Kamil et al.,(2012)found that supplementation with Almond was associated with great reduction in weight. Kim et al.,(2008) suggested that Juniperus chinesis hot water extract reduse BWG in albino rats. Shen et al.,(2005)reported that the scent of Grapefruit reduced appetite and body weight in rats.Fujioka et al.,(2006)suggested that the fresh Grapefruit had effect on body weight in obese patient .Dow et al .,(2012)found that consuming Grapefruit may promote weight loss in overweight adult. Chrubasik et al.,(2008)reported that Sambucus nigra used for weight reduction.

Table (1): Effect of Almond nut,Sambucus herbs,Juniperus seeds, Grapefruit albedo\&the combination of all(as 5\%) on body weight gain(BWG)par 28 days ,(FI)par day and(FER) of reinopathic rats

\begin{tabular}{|c|c|c|c|c|c|c|}
\hline Groups & $\begin{array}{c}\text { BWG } \\
\text { g }\end{array}$ & $\begin{array}{c}\text { percent of } \\
\text { change of } \\
\text { Control }(+) \\
\text { group }\end{array}$ & $\begin{array}{l}\text { FI } \\
\text { g }\end{array}$ & $\begin{array}{l}\text { Percent of } \\
\text { change of } \\
\text { Control(+) } \\
\text { group }\end{array}$ & FER & $\begin{array}{c}\text { Percent of } \\
\text { change of } \\
\text { Control(+) } \\
\text { group }\end{array}$ \\
\hline Groups1 Control (-) & $10.78 \pm 0.27 \mathrm{a}$ & +73.87 & $12.28 \pm 0.63 \mathrm{~b}$ & +19.10 & $0.031 \pm 0.003 \mathrm{a}$ & +106.66 \\
\hline Groups2 Control (+) & 6. $20 \pm 0.68 \mathrm{e}$ & 00.00 & $15.18 \pm 0.75 \mathrm{a}$ & 00.00 & $0.015 \pm 0.002 \mathrm{c}$ & 00.00 \\
\hline Groups 3 Almond nut 5\% & $7.89 \pm 0.18 \mathrm{~b}$ & +26.93 & $12.25 \pm 0.66 \mathrm{~b}$ & +19.30 & $0.023 \pm 0.005 b$ & +53.33 \\
\hline Groups4 Sambucus herbs $5 \%$ & $7.58 \pm 0.11 \mathrm{c}$ & +22.25 & $12.25 \pm 0.48 \mathrm{~b}$ & +19.30 & $0.023 \pm 0.005 b$ & +53.33 \\
\hline Groups5 Juniperus seeds 5\% & $7.67 \pm 0.16 \mathrm{bc}$ & +23.70 & $12.18 \pm 0.55 \mathrm{~b}$ & +19.76 & $0.022 \pm 0.004 \mathrm{~b}$ & +46.66 \\
\hline Groups6 Grapefruit albedo 5\% & $7.00 \pm 0.43 \mathrm{~d}$ & +12.90 & $12.21 \pm 0.61 \mathrm{~b}$ & +19.57 & $0.0204 \pm 0.003 b$ & +36.00 \\
\hline \multirow[t]{2}{*}{ Group $75 \%$ mixture } & $7.25 \pm 0.13 \mathrm{~d}$ & +16.93 & $12.15 \pm 0.47 \mathrm{~b}$ & +19.96 & $0.0213 \pm 0.006 \mathrm{~b}$ & +42.00 \\
\hline & 0.273 & & 0.203 & & 0.018 & \\
\hline
\end{tabular}


Values denote arithmetic means \pm standard deviation of the mean. (a, b ,c and d) in the same column differ significantly at $\mathrm{p} \leq 0.05$ using one way ANOVA test, while those with similar letters are non significantly different.

B-Effect of Almond nut,Sambucus herbs,Juniperus seeds,Grapefruit albedo\&the combination of all on organs weight of reinopathic rats.

\section{1-Liver weight (g):}

Table(2) resalts show the mean value of liver weight $(\mathrm{g})$ of reinopathic rats fed on various diets. It could be noticed that the mean value of liver( g.) of control (+) group was higher than control (-) group,being 5.6 \pm 0.19 \& $3.98 \pm 0.19$ respectively,showing significant difference.All reinopathic rats fed on various diets showed significant decreases in mean values as compared to control (+) group . Numerically the best liver weight was recorded for group 7 (reinopathic rats fed on mixture of all plants) when compared to control (-) group.

\section{2-Kidneys weight (g):}

Table(5) resalts indicate the mean value of kidneys weight $(\mathrm{g})$ of reinopathic rats fed on different diets. It could be noticed that the mean value of kidneys( g.) of control (+) group was higher than control (-) group. All reinopathic rats fed on various diets showed significant decreases in mean values as compared to control (+) group . Numerically the best kidneys weight was reveald for group 7 (reinopathic rats fed on mixture of all plants) when compared to control (-) group.

\section{3-Spleen weight ( $g$ ):}

Table(6) resalts show the mean value of spleen weight $(\mathrm{g})$ of reinopathic rats fed on various diets. It could be observed that the mean value of spleen( g.) of control (+) group was higher than control (-) group. All reinopathic rats fed on various diets showed significant decreases in mean values as compared to control (+) group . Rats fed on groups 7 showed nonsignificant differences when compared to group 1 (healthy rats).Numerically the best kidneys weight was recorded for group 7 (reinopathic rats fed on mixture of all plants) when compared to control (-) group. 
4-Lungs weight (g):

Table(7) data show the mean value of lungs weight $(\mathrm{g})$ of reinopathic rats fed on various diets. It could be revealed that the mean value of lungs (g.) of control (+) group was higher than control (-) group. All reinopathic rats fed on various diets showed significant decreases in mean values as compared to control (+) group . Rats fed on groups 3,4,5,6\&7 showed nonsignificant differences between them. Numerically the better spleens weight was observed for group 7 (reinopathic rats fed on mixture of all plants) when compared to control (-) group.

\section{5-Heart weight (g):}

Table(8) results show the mean value of heart weight $(\mathrm{g})$ of reinopathic rats fed on different diets. It could be indicatled that the mean value of heart( g.) of control (+) group was higher than control (-) group, being $0.89 \pm 0.05 \& 0.41 \pm 0.03$ respectively. All reinopathic rats fed on various diets showed significant decreases in mean values as compared to control (+) group . Rats fed on groups $4 \& 5$ showed nonsignificant differences between them. It could be observed that rats fed on groups $3 \& 7$ showed nonsignificant difference as compared to control (-) group. Numerically the best heart weight was observed for group 7 (reinopathic rats fed on mixture of all plants) when compared to control (-) group. 
Table(2):Effect of Almond nut, Sambucus herbs, Juniperus seeds, Grapefruit albedo \& the combination of all (as5\%) on organs weight (g)of reinopathic

\begin{tabular}{|c|c|c|c|c|c||}
\hline Groups & Liver & Kidneys & Spleen & Lungs & Heart \\
\hline \hline Group 1 control - ve & $3.98 \pm 0.19 \mathrm{e}$ & $1.21 \pm 0.03 \mathrm{~g}$ & $0.51 \pm 0.03 \mathrm{f}$ & $1.02 \pm 0.02 \mathrm{~d}$ & $0.41 \pm 0.03 \mathrm{~d}$ \\
\hline percent of change of Control(+)group & -28.93 & -38.88 & -46.87 & -20.93 & -53.93 \\
\hline Group 2 control + ve & $5.60 \pm 0.28 \mathrm{a}$ & $1.98 \pm 0.05 \mathrm{a}$ & $0.96 \pm 0.05 \mathrm{a}$ & $1.29 \pm 0.06 \mathrm{a}$ & $0.89 \pm 0.05 \mathrm{a}$ \\
\hline percent of change of Control(+)group & 00.00 & 00.00 & 00.00 & 00.00 & 00.00 \\
\hline Group 3 5\% Almond nut & $5.11 \pm 0.23 \mathrm{~b}$ & $1.29 \pm 0.02 \mathrm{e}$ & $0.72 \pm 0.03 \mathrm{~d}$ & $1.11 \pm 0.08 \mathrm{c}$ & $0.43 \pm 0.03 \mathrm{~d}$ \\
\hline percent of change of Control(+)group & -8.75 & -34.85 & -26.53 & -13.95 & -51.68 \\
\hline \begin{tabular}{c} 
Group 4 5\% Sambucus herbs \\
\hline percent of change of Control(+)group
\end{tabular} & $-1.84 \pm 0.14 \mathrm{c}$ & $1.38 \pm 0.06 \mathrm{~d}$ & $0.79 \pm 0.04 \mathrm{c}$ & $1.20 \pm 0.04 \mathrm{~b}$ & $0.49 \pm 0.03 \mathrm{c}$ \\
\hline Group 5 5\% Juniperus seeds & $4.03 \pm 0.16 \mathrm{e}$ & $1.47 \pm 0.04 \mathrm{c}$ & $0.62 \pm 0.02 \mathrm{e}$ & $1.19 \pm 0.03 \mathrm{~b}$ & $0.51 \pm 0.3 \mathrm{c}$ \\
\hline percent of change of Control(+)group & -28.04 & -25.76 & -36.73 & -7.75 & -42.70 \\
\hline Group 6 5\% Grapefruit albedo & $4.25 \pm 0.13 \mathrm{~d}$ & $1.66 \pm 0.05 \mathrm{~b}$ & $0.82 \pm 0.02 \mathrm{~b}$ & $1.15 \pm 0.04 \mathrm{bc}$ & $0.62 \pm 0.02 \mathrm{~b}$ \\
\hline percent of change of Control(+)group & -28.04 & -16.16 & -16.33 & -10.85 & -30.33 \\
\hline Group 7 5 \% mixture of all planets & $3.99 \pm 0.10 \mathrm{e}$ & $1.25 \pm 0.04 \mathrm{f}$ & $0.52 \pm 0.03 \mathrm{f}$ & $1.10 \pm 0.06 \mathrm{c}$ & $0.41 \pm 0.02 \mathrm{~d}$ \\
\hline $\begin{array}{c}\text { percent of change of Control(+)group } \\
\text { LSD }\end{array}$ & -28.75 & -36.87 & -46.94 & -14.73 & -53.93 \\
\hline & 0.179 & 0.039 & 0.027 & 0.062 & 0.031 \\
\hline
\end{tabular}

Values denote arithmetic means \pm standard deviation of the mean. $(a, b$ , c and d) in the same column differ significantly at $\mathrm{p} \leq 0.05$ using one way ANOVA test, while those with similar letters are non significantly different.

C-Effect of Almond nut, Sambucus herbs, Juniperus seeds, Grapefruit albedo\&the combination of all on serum glucose $(\mathrm{mg} / \mathrm{dl})$ of reinopathic rats.

Table(3) data reveal the mean value of serum glucose (mgldl) of reinopathic rats fed on different diets. It could be noticed that the mean value of glucose of control (+) group was higher than control (-) group, being $155.00 \pm 5.00 \& 100.00 \pm 4.34$ respectively, showing significant difference . All reinopathic rats fed on different diets indicated significant decreases in mean values as compared to control (+) group . Numerically the better serum glucose was observed for group 7 (reinopathic rats fed on mixture of all plants) when compared to control (-) group. 
The obtained results are in line with that of Ali,Amal (2011) found that nephritis inflicted rats by gentamicin revealed increase of glucose in serum. Lovejoy et al.,(2002)reported that Almond- enriched diets do not alter insulin sensitivity in health adults or glycemia in patients with diabetes. Jenkins et al.,(2006),(2008) however suggested that Almond may decrease the risk of oxidative damage to protein by decreasing the glycemic excrution. Wien et al.,(2010)found that the Almond- enriched intervention group exhibited greater reduction in insulin. Li et al.,(2011)reported that the Almond consumption is associated with amelioration in hyperglycemia. Kamil and chen(2012)concluded that Almond was usfuel for diabetes. Gray et al,.(2000)demonstrated that Sambucus nigra was a antidiabetic plant. Ciocoiu et al.,(2009)reported that S. nigra represents a possible dietary adjunct for the treatment of diabetes and a potential source for the discovery of new orally active agents for future diabetes therapy. Orhan et al.,(2011),(2012)reported that the treatment of diabetic rats with Juniperus oxycedrus decreased the blood glcose levels in liver and kidney tissues .Ju et al.,(2008) suggested that the ethanolic extract of Chinese juniperus berries reduced the blood glucose levels of alloxan-induced diabetic rats. Fujioka et al.,(2006)suggested that insulin resistance was improved with fresh Grapefruit of obese patient.

Table(3):Effect of Almond nut, Sambucus herbs, Juniperus seeds, Grapefruit albedo \& the combination of all (as $5 \%)$ on serum glucose $(\mathrm{mg} / \mathrm{dl})$ of reinopathic rats

\begin{tabular}{||l|c|c||}
\hline \multicolumn{1}{|c|}{ Groups } & Glucouse & $\begin{array}{c}\text { percent of change of } \\
\text { control( }+ \text { group }\end{array}$ \\
\hline \hline Group 1 control - ve & $100.00 \pm 4.36 \mathrm{~b}$ & -35.48 \\
\hline Group 2 control + ve & $155.00 \pm 5.00 \mathrm{a}$ & 00.00 \\
\hline Group 3 5\% Almond nut & $98.30 \pm 2.86 \mathrm{~b}$ & -36.58 \\
\hline Group 4 5\% Sambucus herbs & $87.50 \pm 0.12 \mathrm{~cd}$ & -43.54 \\
\hline Group 5 5\% Juniperus seeds & $90.40 \pm 2.51 \mathrm{c}$ & -41.68 \\
\hline Group 6 5\% Grapefruit albedo & $90.00 \pm 4.36 \mathrm{c}$ & -41.94 \\
\hline Group 7 5\%mixture & $84.00 \pm 2.65 \mathrm{~d}$ & -45.81 \\
\hline LSD & 5.041 & \\
\hline
\end{tabular}


Values denote arithmetic means \pm standard deviation of the mean. Means with different letters(a, b and $c)$ in the same

column different significantly at $\mathrm{p} \leq 0.05$ using one way ANOVA test, while those with similar letters are non significantly different

D-Effect of Almond nut,Sambucus herbs, Juniperus seeds, Grapefruit albedo \& the combination of all on total cholesterole (T.C.), triglycerides (T.G), high density lipoprotein cholesterol (H.D.L.c), Low density lipoprotein cholesterol of (L.D.Lc), very low density lipoproteins cholesterol (V.L.D.Lc) \& atherogenic index(A.I.) of reinopathic rats .

\section{1-Total cholesterole(T.C.)mg/dl :}

Data of table(4) illustrate the mean value of serum(T.C.) (mgldl) of reinopathic rats fed on different diets. It could be observed that the mean value of(T.C.) of control (+) group was higher than control (-) group,being $141.00 \pm 3.46 \& 118.00 \pm 2.65$ respectively,showing significant difference. All reinopathic rats fed on different diets revealed significant decreases in mean values as compared to control (+) group . Numerically the better serum (T.C) was showed for group 5 (reinopathic rats fed on Juniperus seeds) when compared to control (-) group.

\section{2-Triglycerides(T.G.)mgldl :}

Table(4) results show the mean value of serum(T.G.) (mgldl) of reinopathic rats fed on different diets. It could be noticed that the mean value of(T.G.) of control (+) group was higher than control (-) group, being $152.00 \pm 7.21 \& 130.00 \pm 4.55$ respectively, indicating significant difference . All reinopathic rats fed on different diets revealed significant decreases in mean values as compared to control (+) group . Feeding on Juniperus group revealed nonsignificant different of(T.G.) as compared to control (-) group. Numerically the best serum (T.G.) was recorded for group 7 (reinopathic rats fed on mixture of plants) when compared to control (-) group.

\section{3-High density lipoprotein cholesterol(H.D.Lc)mgldl:}

Table(4) data indicate the mean value of serum (HDLc) (mgldl) of reinopathic rats fed on different diets. It could be observed that the mean 
value of (HDLc) of control (+) group was lower than control (-) group, being $74.30 \pm 5.14 \& 88.30 \pm 2.86$ respectively, showing significant difference. All reinopathic rats fed on different diets revealed significant increases in mean values as compared to control $(+)$ group . Numerically the best serum (HDLc) was obseved for group $6 \& 7$ (reinopathic rats fed on Grapefruit albedo \& mixture of plants) when compared to control (-) group.

\section{4-Low density lipoprotein cholesterol(L.D.Lc)mgldl:}

Data in table(4) illustrat the mean value of serum(LDLc) (mgldl) of reinopathic rats fed on different diets. It could be observed that the mean value of(LDLc) of control (+) group was higher than control (-) group,being $36.30 \pm 4.07 \& 3.70 \pm 0.08$ respectively,showing significant . All reinopathic rats fed on different diets revealed significant decreases in mean values as compared to control (+) group . Rats fed on group 3( Almond nut) revealed nonosignificant differences as compared to control (-) group, and recorded the best serum (LDLc).

\section{5- Very low density lipoprotein cholesterol(V.L.D.Lc)mgldl:}

Data of table(4) indicate the mean value of serum (VLDLc) (mgldl) of reinopathic rats fed on different diets. It could be observed that the mean value of (VLDLc) of control (+) group was higher than control (-) group, being $\quad 30.40 \pm 3.98 \& 26.00 \pm 2.57$ respectively, showing significant difference . All reinopathic rats fed on different diets showed significant decreases in mean values as compared to control (+) group . Rats fed on group . The best treatment was recorded for group7 Atherogenic Index(A.I.)ratio.

Data of table(4) revealed that the mean value of serum(A.I.) (mgldl) of reinopathic rats fed on different diets. It could be noticed that the mean value of(A.I.) of control (+) group was higher than control (-) group,being $0.892 \pm 0.09 \& 0.34 \pm 0.01$ respectively, showing significant difference . All reinopathic rats fed on various diets showed significant decreases in mean values as compared to control (+) group . Rats fed on group Numerically the best treatment was recorded for group7 considering serum (A.I.). 
The obtained results are in line with that of Ali, Amal (2011)who found that nephritis inflicted rats by gentamicin caused increase of T.L. , T.G. , LDLc , VLDLc \& decrease of HDLc in serum. Wien et al., (2003) reported that supplementation with Almond was associated with great reduction in T.C., T. G., LDLc , VLDLc \&increase in HDLc with type 2 diabetics. Li et al.,(2011) found that Almond consumption is associated with hypolipidemia. Rajaram et al ., (2010)showed that consumption of Almond nut lower blood lipids and risk of CHD. Spiller et al.,(1992),(1998)found that there was a rapid reduction in low density LDLc, TC without change in HDL in humans when consumption Almond nut. Jenkins et al.,(2002) found that the Almond decreased the level of blood lipids(LDLc) and (LDLc: HLDc) reduce coronary heart disease risk factor for the hiperlipidemic subjects. Lovejoy et al .,(2008) found that Almond-enrich diet had beneficial effects on serum lipids in healthy adults. Jaceldo et al .,(2011) repoted that Almond had cholesterol lowering effect. Ciocoiu et al.,(2009)found that the polyphnols of Sambucus nigra reduce the lipid peroxides, neutralize the lipidi peroxil radicals and inhibit the LDL oxidation. Murkovic et al., (2004) reported that Sambucus spray -dried extract at a low dose exerts a minor effect on serum lipids and antioxidative capacity higher , but nutritionally relevant doses might significantly reduce post prandial serum lipids. Ju et al.,(2008)suggested that the aqueous extract of Chinese juniperus had a potential hypolipidemic effect. Kim et al.,(2008) reported that Juniperus chinesis hot water extract reduce blood lipids levels of alino rats.Orhan et al.,(2011)found that the treatment of diabetic rats with Juniperus oxycedrus decrease both the levels of lipid peroxidation in liver \&kidney tissues. Rincon et al .,(2005) suggested that Grapfruits peels had the highest ascorbic acid and carotenoid content, good source of dietary fiber and phenolic compound whose use could be useful in the formulation of fuctional foods and suitable to reduce risk of some disease such as cardiovascular and some associated to lipid oxidation. Vinson et al.,(2002)reported that the juice of grapefruit was able to significantly inhibit atherosclerosis and lowerd cholesterol \& triglycerids. 
Table(4): Effect of Almond nut, Sambucus herbs, Juniperusseeds, Grapefruit albedo \& the combination of all on total cholesterole (T.C.), triglycerides(T.G), high density lipoprotein cholesterol (H.D.L.c) , Low density lipoprotein cholesterol of (L.D.Lc), very low density lipoproteins cholesterol (V.L.D.Lc) \& atherogenic index(A.I.) of reinopathic rats

\begin{tabular}{|c|c|c|c|c|c|c|}
\hline Groups & $\begin{array}{c}\text { Total } \\
\text { Cholesterol } \\
(\mathrm{mg} / \mathrm{dl}) \\
\end{array}$ & $\begin{array}{c}\text { Triglycerides } \\
(\mathrm{mg} / \mathrm{dl})\end{array}$ & HDLc.(mg/dl) & LDLc.(mg/dl) & $\begin{array}{l}\text { LDLc. } \\
(\mathrm{mg} / \mathrm{dl})\end{array}$ & A.I \\
\hline $\begin{array}{c}\text { Group } 1 \\
\text { control - ve }\end{array}$ & $118.00 \pm 2.65 \mathrm{c}$ & $130.00 \pm 4.55 \mathrm{c}$ & $88.30 \pm 2.86 \mathrm{ab}$ & $3.70 \pm 0.08 \mathrm{ef}$ & $26.00 \pm 3.57 b$ & $0.34 \pm 0.01 \mathrm{~cd}$ \\
\hline $\begin{array}{c}\text { percent of change of } \\
\text { Control(+)group }\end{array}$ & -16.31 & -14.47 & +18.84 & -89.81 & -14.47 & -61.88 \\
\hline $\begin{array}{c}\text { Group } 2 \\
\text { control + ve }\end{array}$ & $141.00 \pm 3.46 \mathrm{a}$ & $152.00 \pm 7.21 \mathrm{a}$ & $74.30 \pm 5.14 \mathrm{c}$ & $36.3 \pm 4.07 \mathrm{a}$ & $30.40 \pm 3.98 \mathrm{a}$ & $0.892 \pm 0.09 \mathrm{a}$ \\
\hline $\begin{array}{c}\text { percent of change of } \\
\text { Control(+)group } \\
\end{array}$ & 00.00 & 00.00 & 00.00 & 00.00 & 00.00 & 00.00 \\
\hline $\begin{array}{cc} & \text { Group } 3 \\
& \text { 5\% } \\
\text { Almond nut }\end{array}$ & $119.00 \pm 5.19 \mathrm{c}$ & $147.00 \pm 2.64 \mathrm{~b}$ & $\begin{array}{c}87.80 \pm 2.55 \\
\mathrm{ab} \\
\end{array}$ & $1.80 \pm 0.07 \mathrm{f}$ & $\begin{array}{c}29.40 \pm 1.51 \\
\mathrm{a} \\
\end{array}$ & $0.36 \pm 0.02 \mathrm{~cd}$ \\
\hline $\begin{array}{c}\text { percent of change of } \\
\text { Control(+)group } \\
\end{array}$ & -15.60 & -3.29 & +18.16 & -96.42 & -3.28 & -59.64 \\
\hline $\begin{array}{c}\text { Group } 4 \\
5 \% \text { Sambucus herbs }\end{array}$ & $118.60 \pm 3.14 \mathrm{c}$ & $116.50 \pm 3.04 \mathrm{~d}$ & $85.30 \pm 2.07 \mathrm{~b}$ & $9.5 \pm 0.78 b c$ & $\begin{array}{c}23.30 \pm 2.07 \\
\mathrm{c}\end{array}$ & $0.38 \pm 0.01 \mathrm{c}$ \\
\hline $\begin{array}{c}\text { percent of change of } \\
\text { Control(+)group } \\
\end{array}$ & -16.31 & -23.36 & +14.80 & -73.83 & -23.35 & -57.40 \\
\hline \begin{tabular}{|c|} 
Group 5 \\
$5 \%$ Juniperus seeds
\end{tabular} & $109.00 \pm 4.35 \mathrm{~d}$ & $131.00 \pm 3.46 \mathrm{c}$ & $75.00 \pm 3.46 c$ & $7.80 \pm 0.10 \mathrm{~cd}$ & $\begin{array}{c}26.20 \pm 1.59 \\
b\end{array}$ & $0.45 \pm 0.02 b$ \\
\hline $\begin{array}{c}\text { percent of change of } \\
\text { Control }(+) \text { group } \\
\end{array}$ & -22.70 & -13.82 & +0.942 & -78.51 & -31.81 & -49.55 \\
\hline $\begin{array}{c}\text { Group } 6 \\
\text { 5\% Grapefruit } \\
\text { albedo }\end{array}$ & $130.50 \pm 3.91 b$ & $145.60 \pm 5.11 b$ & $90.00 \pm 4.36 \mathrm{a}$ & $11.38 \pm 0.53 b$ & $\begin{array}{c}29.12 \pm 1.65 \\
\mathrm{a}\end{array}$ & $0.45 \pm 0.03 b$ \\
\hline \begin{tabular}{|c} 
percent of change of \\
Control(+)group \\
\end{tabular} & -7.45 & -4.21 & +21.13 & -68.65 & -4.27 & -49.55 \\
\hline \begin{tabular}{|c} 
Group 7 \\
$5 \%$ mixture of all \\
planets \\
\end{tabular} & $118.00 \pm 2.52 \mathrm{c}$ & $113.00 \pm 2.57 \mathrm{~d}$ & $90.00 \pm 4.13 \mathrm{a}$ & $5.40 \pm 0.08 \mathrm{de}$ & $22.60 \pm 2.51 \mathrm{c}$ & $0.31 \pm 0.01 \mathrm{~d}$ \\
\hline $\begin{array}{c}\text { percent of change of } \\
\text { Control(+)group }\end{array}$ & -16.31 & -25.66 & +21.13 & -85.12 & -25.65 & -62.25 \\
\hline LSD & 3.517 & 4. 792 & 3.672 & 2.675 & 2.086 & 0.314 \\
\hline
\end{tabular}


Values denote arithmetic means \pm standard deviation of the mean. Means with different letters ( $a, b$ and $c$ ) in the same column different significantly at $\mathrm{p} \leq 0.05$ using one way ANOVA test, while those with similar letters are nonsignificantdifferent.

E-Effect of Almond nut, Sambucus herbs, Juniperus seeds, Grapefruit albedo \& the combination of all on kidney function of reinopathic rats.

\section{1-Serum creatinine (mg/dl):}

Data of table (5) indicated the mean value of serum creatinine $(\mathrm{mg} / \mathrm{dl})$ of reinopathic rats fed on various diets. It could be observed that the mean value of creatinine of control (+) group was higher than control (-) group, being $1.20 \pm 0.03 \& 0.50 \pm 0.03$ respectively,showing significant difference . All reinopathic rats fed on different diets revealed significant decreases in mean values as compared to control (+) group. Groups $3 \& 7$ indicated nonosignificant differences when compared to control (-) group and revealed the best treatment.

\section{2-Serum urea $(\mathrm{mg} / \mathrm{dl})$ :}

Data of table(5) illusterate the mean value of serum urea $(\mathrm{mg} / \mathrm{dl})$ of reinopathic rats fed on various diets. It could be noticed that the mean value of urea of control (+) group was higher than control (-) group,being 110.00 $\pm 4.58 \& 20.00 \pm 1.76 \mathrm{mg} / \mathrm{dl}$ respectively,indicating significant difference . All reinopathic rats fed on different diets revealed significant decreases in mean values as compared to control $(+)$ group. The best treatment was recorded for group 7(mixture of all plants) when compared to control (+) group.

\section{3-Serum uric acid(U. A.) (mg/dl):}

Table(5) results show the mean value of $\operatorname{serum}(\mathrm{U}$. A) $(\mathrm{mg} / \mathrm{dl})$ of reinopathic rats fed on various diets. It could be observed that the mean value of uric acid of control (+) group was higher than control (-) group,being $7.70 \pm 0.03 \& 1.70 \pm 0.03 \mathrm{mg} / \mathrm{dl}$ respectively,indicating significant difference. All reinopathic rats fed on various diets revealed significant decreases in mean values as compared to control (+) group . 
The best treatment was recorded for group 7(mixture of all plants) when compared to control (+) group.

It seems possible that the used plants could correct the changes in kidneys function due to injection of rats with gentamicin .

Table(5): Effect of Almond nut, Sambucus herbs, Juniperus seeds, Grapefruit albedo $\&$ the combination of all on kidney function of reinopathic rats

\begin{tabular}{|c|c|c|c|c|c|c|}
\hline Groups & $\begin{array}{c}\text { Serum } \\
\text { creatinine } \\
(\mathrm{mg} / \mathrm{dl})\end{array}$ & $\begin{array}{c}\text { percent of } \\
\text { change of } \\
\text { control(+)group }\end{array}$ & $\begin{array}{c}\text { Serum } \\
\text { urea } \\
(\mathrm{mg} / \mathrm{dl})\end{array}$ & $\begin{array}{c}\text { percent of } \\
\text { change of } \\
\text { control(+)group }\end{array}$ & $\begin{array}{l}\text { Serum uric } \\
\operatorname{acid}(\mathrm{mg} / \mathrm{dl})\end{array}$ & \begin{tabular}{|c|} 
percent of \\
change of \\
control(+)group
\end{tabular} \\
\hline $\begin{array}{c}\text { Group } 1 \\
\text { control - ve }\end{array}$ & $\begin{array}{l}0.50 \pm \\
0.03 \mathrm{e}\end{array}$ & -58.33 & $\begin{array}{c}20.00 \pm \\
1.76 \mathrm{e} \\
\end{array}$ & -81.81 & $1.70 \pm 0.03 \mathrm{e}$ & -77.92 \\
\hline $\begin{array}{c}\text { Group } 2 \\
\text { control + ve }\end{array}$ & $\begin{array}{r}1.20 \\
\pm 0.08 \mathrm{a}\end{array}$ & 00.00 & $\begin{array}{r}110.00 \\
\pm 4.58 \mathrm{a}\end{array}$ & 00.00 & $7.70 \pm 0.60 \mathrm{a}$ & 00.00 \\
\hline $\begin{array}{c}\text { Group } 3 \\
\text { 5\% Almond nut }\end{array}$ & $\begin{array}{l}0.55 \pm \\
0.04 \mathrm{~d}\end{array}$ & -54.16 & $\begin{array}{c}39.00 \pm 1 \\
73 \mathrm{c}\end{array}$ & -64.54 & $4.90 \pm 0.36 \mathrm{~b}$ & -36.36 \\
\hline $\begin{array}{c}\text { Group } 4 \\
5 \% \text { Sambucus herbs }\end{array}$ & $\begin{array}{r}0.68 \\
\pm 0.03 \mathrm{~b} \\
\end{array}$ & -43.33 & $\begin{array}{r}1.30 \\
\pm 2.01 \mathrm{c} \\
\end{array}$ & -62.45 & $4.80 \pm 0.39 \mathrm{~b}$ & -37.66 \\
\hline $\begin{array}{c}\text { Group } 5 \\
\text { 5\% Juniperus seeds }\end{array}$ & $\begin{array}{c}0.70 \\
\pm 0.02 \mathrm{~b}\end{array}$ & -41.66 & $\begin{array}{c}56.30 \pm \\
1.54 \mathrm{~b}\end{array}$ & -48.81 & $4.3 \pm 0.26 c$ & -44.15 \\
\hline \begin{tabular}{|c|} 
Group 6 \\
$5 \%$ Grapefruit albedo \\
\end{tabular} & $\begin{array}{r}0.60 \\
\pm 0.02 \mathrm{c} \\
\end{array}$ & -50 & $\begin{array}{r}55.30 \\
\pm 1.13 \mathrm{~b} \\
\end{array}$ & -49.72 & $4.00 \pm 0.24 \mathrm{c}$ & -48.05 \\
\hline \begin{tabular}{|c|} 
Group 7 \\
$5 \%$ mixture of all planets
\end{tabular} & $\begin{array}{c}0.55 \\
\pm 0.03 \mathrm{~d} \\
\end{array}$ & -54.16 & $\begin{array}{c}33.20 \pm 1 \\
06 \mathrm{~d}\end{array}$ & -69.81 & $2.50 \pm 0.04 \mathrm{~d}$ & -67.53 \\
\hline LSD & 0.041 & & 2.521 & & 0.404 & \\
\hline
\end{tabular}

Values denote arithmetic means \pm standard deviation of the mean. Means with different letters ( $a, b$ and $c$ ) in the same column different significantly at $\mathrm{p} \leq 0.05$ using one way ANOVA test, while those with similar letters are nonsignificantdifferent.

\section{4-Electrolytes (m.eq/l):}

\section{A-Serum sodium $(\mathrm{Na})$ \&potassium $(k)($ m.eq/l)}

Table (6) results show the mean value of serum $(\mathrm{Na}) \&(\mathrm{k})(\mathrm{m} . \mathrm{eq} / \mathrm{l})$ of reinopathic rats fed on various diets. It could be observed that the mean values of $\mathrm{Na} \& \mathrm{k}$ of control (+) group were lower than control (-) group,being( $\quad 36.20 \pm 2.45 .03 \& 199.00 \pm 7.94) \&(2.80 \pm 0.26 \& 12.40 \pm 0.35)$ $\mathrm{m} . e q / \mathrm{l}$ respectively,indicating significant differences . Rats fed on various 
diets revealed significant increases in mean values as compared to control (+) group . The best treatment was recorded for group 7(mixture of all plants) when compared to control (-) group.

It seems possible that the used plants could correct the changes in serum electrolytes $\mathrm{Na} \& \mathrm{~K}$ due to injection of rats with gentamicin .

\section{B-Urine sodium $(\mathrm{Na})$ \&potassium $(k)(\mathrm{m} . e q / l)$}

Table (6) results indicate the mean value of urin $(\mathrm{Na}) \&(\mathrm{k})(\mathrm{m} . \mathrm{eq} / \mathrm{l})$ of reinopathic rats fed on various diets. It could be noticed that the mean values of $\mathrm{Na} \& \mathrm{k}$ of control (+) group were higher than control (-) group, being( $245.00 \pm 15.09 \& \quad 95.00 \quad \pm 3.46) \&(96.30 \pm 5.48 \quad \& 44.10 \pm 2.7) \quad \mathrm{m} . \mathrm{eq} / \mathrm{l}$ respectively, indicating significant differences . Rats fed on various diets showed significant decreases in mean values as compared to control $(+)$ group. The best treatment was recorded for group 7(mixture of all plants)for both $\mathrm{Na} \& \mathrm{k}$ when compared to control (-) group.

It seems possible that the used plants could correct the changes in urine electrolytes $\mathrm{Na} \& \mathrm{~K}$ due to injection of rats with gentamicin .

Such results are in agreement with that recorded by EL - Moselhy , Shimaa (2007), Sheir , Marwa (2009)\&Ali , Amal (2011), who reported that creatinine, urea\& uric acid level was decreased by treatment with herbal combination of some plants.

Anon (2012a),found that Almond oil had diuretic effect in human body.

Anon (2012b) ,reported that the decoction of the inner bark of Sambucus is used freely as a diuretic in the treatment of acute nephritis. Anon (2012c),found that Sambucus used for nephritis -edema with $12-25 \mathrm{~g}$ drug material from entire plant in decoction. Dzharullaeva et al .,(2009) found that the main biologically active substances are flavonoids (1.61\%) in Juniperus oxycedrus and possess the diuretic effect. Tumen et al.,(2012) reported that Juniperus sp. is mainely used as diuretic in Turkish folk.

Goldfarb et al., (2001) suggested that grapefruit juice ingestion was associated with an increase in mean oxalate excretion and citrate excretion. 
Trinchieri et al.,(2002) showed that grapefruit juice increased urinary excretion of citrate and calcium, magnesium in healthy subjects. Honow et al .,(2003)reported that both grapefruit and apple juices reduced the risk of calcium oxalate stone formation.

Table(6): Effect of Almond nut, Sambucus herbs, Juniperus seeds, Grapefruit albedo \& the combination of all(as5\%) on serum and urine sodium $\mathrm{Na}$ and $\mathrm{k}(\mathrm{m} . \mathrm{eq} / \mathrm{l})$ of reinopathic rats

\begin{tabular}{|c|c|c|c|c|c|c|c|c|}
\hline \multicolumn{5}{|c|}{ serum } & \multicolumn{4}{|c|}{ Urine } \\
\hline Groups & $\mathrm{Na}$ & $\begin{array}{c}\text { percent of } \\
\text { change of } \\
\text { Control }(+) \\
\text { group }\end{array}$ & $\mathrm{K}$ & $\begin{array}{c}\text { percent of } \\
\text { change of } \\
\text { Control(+) } \\
\text { group } \\
\end{array}$ & $\mathrm{Na}$ & $\begin{array}{c}\text { percent of } \\
\text { change of } \\
\text { Control(+) } \\
\text { group } \\
\end{array}$ & $\mathrm{K}$ & $\begin{array}{c}\text { percent of } \\
\text { change of } \\
\text { Control(+)gro } \\
\text { up } \\
\end{array}$ \\
\hline $\begin{array}{c}\text { Group } 1 \\
\text { control - ve }\end{array}$ & $\begin{array}{r}199.00 \\
\pm 7.94 \mathrm{a} \\
\end{array}$ & +342.85 & $\begin{array}{c}12.40 \pm \\
0.53 b\end{array}$ & +342.86 & $\begin{array}{c}95.00 \pm \\
3.46 \mathrm{c} \\
\end{array}$ & -62.59 & $\begin{array}{c}44.10 \pm \\
2.71 \mathrm{~d} \\
\end{array}$ & -54.20 \\
\hline $\begin{array}{c}\text { Group } 2 \\
\text { control + ve }\end{array}$ & $\begin{array}{c}36.00 \pm \\
2.45 \mathrm{f} \\
\end{array}$ & 00.00 & $\begin{array}{l}2.80 \pm \\
0.26 \mathrm{f} \\
\end{array}$ & 00.00 & $\begin{array}{c}254.00 \pm \\
15.09 \mathrm{a} \\
\end{array}$ & 00.00 & $\begin{array}{c}96.30 \pm \\
5.48 \mathrm{a} \\
\end{array}$ & 00.00 \\
\hline \begin{tabular}{cc}
\multicolumn{1}{c}{ Group 3} \\
$5 \%$ & Almond nut \\
\end{tabular} & $\begin{array}{c}176.00 \pm \\
5.29 \mathrm{c}\end{array}$ & +185.71 & $\begin{array}{l}8.00 \pm \\
0.37 \mathrm{c}\end{array}$ & +185.71 & $\begin{array}{c}95.00 \pm \\
3.46 \mathrm{c} \\
\end{array}$ & -62.59 & $\begin{array}{c}54.00 \pm \\
4.36 \mathrm{c} \\
\end{array}$ & -43.92 \\
\hline $\begin{array}{c}\text { Group } 4 \\
5 \% \text { Sambucus } \\
\text { herbs }\end{array}$ & $\begin{array}{c}157.00 \pm \\
6.08 \mathrm{~d}\end{array}$ & +46.42 & $\begin{array}{c}4.10 \pm 0 \\
26 \mathrm{e}\end{array}$ & +46.43 & $\begin{array}{r}97.00 \\
\pm 3.61 \mathrm{c}\end{array}$ & -61.81 & $\begin{array}{c}54.60 \pm 4 \\
51 \mathrm{c}\end{array}$ & -43.30 \\
\hline $\begin{array}{c}\text { Group } 5 \\
\text { 5\% Juniperus seeds }\end{array}$ & $\begin{array}{c}145.30 \pm \\
5.02 \mathrm{e} \\
\end{array}$ & +85.71 & $\begin{array}{c}5.20 \pm 0 \\
45 \mathrm{~d}\end{array}$ & +85.71 & $\begin{array}{c}106.00 \pm \\
4.36 b\end{array}$ & -58.26 & $\begin{array}{c}63.70 \pm 3 \\
25 \mathrm{~b} \\
\end{array}$ & -33.85 \\
\hline $\begin{array}{c}\text { Group } 65 \% \\
\text { Grapefruit albedo }\end{array}$ & $\begin{array}{l}154.30 \\
\pm 5.14 \mathrm{~b}\end{array}$ & +60.71 & \begin{tabular}{|c|}
4.50 \\
$\pm 0.75 \mathrm{e}$
\end{tabular} & +60.71 & $\begin{array}{c}94.00 \pm \\
5.29 \mathrm{c}\end{array}$ & -62.99 & $\begin{array}{r}54.00 \\
\pm 3.61 \mathrm{c}\end{array}$ & -43.92 \\
\hline $\begin{array}{c}\text { Group } 7 \\
5 \% \text { mixture }\end{array}$ & $\begin{array}{r}181.00 \\
\pm 3.41 \mathrm{~b}\end{array}$ & +571.42 & $\begin{array}{c}18.80 \pm \\
0.15 \mathrm{a}\end{array}$ & +571.42 & $\begin{array}{c}94.00 \pm \\
3.49 \mathrm{c}\end{array}$ & -62.99 & $\begin{array}{c}42.60 \pm \\
2.51 \mathrm{~d}\end{array}$ & -55.76 \\
\hline LSD & 4.454 & & 0.689 & & 8.367 & & 3.198 & \\
\hline
\end{tabular}

Values denote arithmetic means \pm standard deviation of the mean. Means with different letters ( $a, b, c$ and d) in the same column different significantly at $\mathrm{p} \leq 0.05$ using one way ANOVA test, while those with similar letters are nonsignificantdifferent. 
F-Effect of Almond nut, Sambucus herbs, Juniperus seeds, Grapefruit albedo \& the combination of all on liver function of reinopathic rats.

1-Serum glutamic oxaloacetate transaminase (GOT) or (AST) enzyme $(U / L):$

Data of table(7) illustrate the mean value of serum (GOT) (U/L) of reinopathic rats fed on various diets. It could be noticed that the mean value of (GOT)of control (+) group was higher than control (-) group,being 60.00 $\pm 5.00 \& 16.00 \pm 2.51$ respectively,showing significant difference . All reinopathic rats fed on different diets revealed significant decreases in mean values as compared to control (+) group. Mixture of all plants(group7) revealed the best treatment when compared to control (+) group considering (GOT) activity.

\section{2-Serum glutamic pyruvate transaminase (GPT) or(ALT)enzyme (U/L):}

Data of table(7) show the mean value of serum (GPT) (U/L) of reinopathic rats fed on different diets. It could be observed that the mean value of (GPT)of control (+) group was higher than control (-) group,being $11.20 \pm 1.05 \& 4.00 \pm 0.61$ respectively,showing significant difference . All reinopathic rats fed on various diets revealed significant decreases in mean values as compared to contro $1(+)$ group. Group( 7) which was the best treatment considering the GPT activity showed nonosignificant difference, in comparison with group (1) of healthy rats.

\section{3-Serum alkaline phosphatase (ALP) enzyme (U/L):}

Data of table(7) illustrate the mean value of serum (ALP) (U/L) of reinopathic rats fed on various diets. It could be noticed that the mean value of (ALP)of control (+) group was higher than control (-) group,being $249.20 \pm 10.15 \& 87.00 \pm 2.13$ respectively, indicated significant difference . All reinopathic rats fed on various diets revealed significant decreases in mean values as compared to control (+) group.Numerically the mixture of all pants diet recorded the better treatment of serum ALP. 


\section{4-Serum $(G O T) /(G P T)$ or $(A S T) /(A L T)$ ratio $(U / L)$ :}

Data of table(7) indicate the mean value of serum(GOT)/ (GPT)ratio (U/L) of reinopathic rats fed on various diets. It could be noticed that the mean value of (GOT)/(GPT)ratio of control (+) group was higher than control (-) group, being $5.40 \pm 0.25 \& 4.00 \pm 0.34$ respectively, showing significant . All reinopathic rats fed on various diets revealed significant decreases in mean values as compared to control (+) group. The best treatment considering the GOT/ GPT ratio was recorded for group "7" in comparison with group (2).

Table(7): Effect of Almond nut, Sambucus herbs, Juniperus seeds, Grapefruit albedo $\&$ the combination of all on liver function of reinopathic rats.

\begin{tabular}{|c|c|c|c|c|}
\hline Groups & GOT or AST(U/L) & GPTor ALT(U/L & $\mathrm{ALP}(\mathrm{U} / \mathrm{L})$ & AST/ALT(U/L)* \\
\hline $\begin{array}{c}\text { Group } 1 \\
\text { control - ve }\end{array}$ & $16.00 \pm 2.51 \mathrm{~d}$ & $4.00 \pm 0.61 \mathrm{e}$ & $87.00 \pm 2.13 \mathrm{de}$ & $4.00 \pm 0.34 \mathrm{e}$ \\
\hline $\begin{array}{c}\text { percent of change of } \\
\text { Control }(+) \text { group } \\
\end{array}$ & -73.33 & -64.28 & -65.06 & -25.92 \\
\hline $\begin{array}{c}\text { Group } 2 \\
\text { control + ve }\end{array}$ & $60.00 \pm 5.00 \mathrm{a}$ & $11.20 \pm 1.05 \mathrm{a}$ & $249.00 \pm 10.15 a$ & $5.40 \pm 0.25 \mathrm{a}$ \\
\hline $\begin{array}{l}\text { percent of change of } \\
\text { Control(+)group }\end{array}$ & 00.00 & 00.00 & 00.00 & 00.00 \\
\hline $\begin{array}{c}\text { Group } 3 \\
5 \% \text { Almond nut }\end{array}$ & $24.00 \pm 2.75 \mathrm{c}$ & $5.00 \pm 0.45 \mathrm{~d}$ & $82.00 \pm 2.65 \mathrm{ef}$ & $4.80 \pm 0.17 \mathrm{c}$ \\
\hline $\begin{array}{c}\text { percent of change of } \\
\text { Control(+)group } \\
\end{array}$ & -60 & -55.35 & -67.06 & -11.11 \\
\hline $\begin{array}{c}\text { Group } 4 \\
5 \% \text { Sambucus herbs }\end{array}$ & $29.00 \pm 3.61 \mathrm{c}$ & $6.00 \pm 0.26 \mathrm{c}$ & $116.00 \pm 5.29 \mathrm{c}$ & $4.80 \pm 0.17 \mathrm{c}$ \\
\hline $\begin{array}{l}\text { percent of change of } \\
\text { Control(+)group }\end{array}$ & -51.66 & -48.42 & -53.41 & -11.11 \\
\hline $\begin{array}{c}\text { Group } 5 \\
5 \% \text { Juniperus seeds }\end{array}$ & $45.00 \pm 3.55 b$ & $9.00 \pm 0.28 b$ & $79.00 \pm 2.57 \mathrm{c}$ & $5.00 \pm 0.26 b c$ \\
\hline $\begin{array}{c}\text { percent of change of } \\
\text { Control(+)group }\end{array}$ & -25 & -19.64 & -64.04 & -7.40 \\
\hline $\begin{array}{c}\text { Group } 6 \\
5 \% \text { Grapefruit albedo }\end{array}$ & $25,00 \pm 1.73 \mathrm{c}$ & $4.80 \pm 0.45 \mathrm{~d}$ & $90.00 \pm 4.19 \mathrm{~d}$ & $5.20 \pm 0.23 \mathrm{ab}$ \\
\hline $\begin{array}{c}\text { percent of change of } \\
\text { Control(+)group } \\
\end{array}$ & -58.33 & -57.14 & -75.90 & -3.70 \\
\hline $\begin{array}{c}\text { Group } 7 \\
5 \% \text { mixture of all planets } \\
\end{array}$ & $18.00 \pm 1.00 \mathrm{~d}$ & $4.00 \pm 0.34 \mathrm{e}$ & $78.00 \pm 2.64 \mathrm{f}$ & $4.50 \pm 0.26 \mathrm{~d}$ \\
\hline $\begin{array}{c}\text { percent of change of } \\
\text { Control(+)group }\end{array}$ & -70 & -64.28 & -68.67 & -16.66 \\
\hline LSD & 4.910 & 0.596 & 6.095 & 0.260 \\
\hline
\end{tabular}




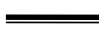

(U/L)* means unit per liter Values denote arithmetic means \pm standard deviation of the mean. Means with different letters ( $a$ and $b$ ) in the same column differ significantly at $p$ $\leq 0.05$ using one way ANOVA test, while those with similar letters are nonsignificantdifferent.

\section{5-Serum and urine total protein $(\mathrm{mg} / \mathrm{dl})$ :}

\section{a-Serum total protein(T.P.):}

Data of table(8) show the mean value of serum(T.P.) $(\mathrm{mg} / \mathrm{dl})$ of reinopathic rats fed on various diets. It could be observed that the mean value of (T.P.) of control (+) group was lower than control (-) group, being $5.60 \pm 0.36 \& 11.30 \pm 0.26$ respectively, indicating significant . All reinopathic rats fed on different diets showed significant increases in mean values as compared to control (+) group. The best treatment considering the serum T.P. in sehwan was recorded for group (7) in comparison with group (2) .

\section{b-Urine total protein(T.P.):}

Data of table(8) indicate the mean value of urine(T.P.) $(\mathrm{mg} / \mathrm{dl})$ of reinopathic rats fed on various diets. It could be noticed that the mean value of (T.P.) of control (+) group was higher than control (-) group,being 4.90 $\pm 0.52 \& 3.20 \pm 0.13$ respectively, indicating significant difference . All reinopathic rats fed on different diets revealed significant decreases in mean values as compared to control (+) group. Numerically the best treatment considering the urine T.P. was recorded for group (5).

These results seemed to agree with that found by El- Moselhy , Shimaa (2007)and Ali, Amal (2011) rising plants and herbes. Jenkins et al ,(2006) suggested that Almond may decrease the risk of oxidative damage to protein by decreasing glycemic excursion and decreased risk CHD . Zhu et al.,(2008)reported that the extraction of S.chinensis by $75 \%$ alcohol showed very significant protective effects on mice acute hepatic injury induced by CCl4. Orhan et al.,(2012)reported that Juniperus berries decreased liver enzymes ,ALP of diabetic rats. Dakovic et al.,(1999) found that the liver protein enzyme content is significantly decreased after the multiple oral Grapefruit juice ingestion of male mice . 
Table(8): Effect of Almond nut, Sambucus herbs, Juniperus seeds, Grapefruit albedo \& the combination of all (as5\%) on serum protein $(\mathrm{mg} / \mathrm{dl})$ of reinopathic rats

\begin{tabular}{|c|c|c|c|c||}
\hline Groups & T.P (serum) & $\begin{array}{c}\text { Percent of } \\
\text { change of } \\
\text { control(+)group }\end{array}$ & T.P Urine & $\begin{array}{c}\text { Percent of change of } \\
\text { control(+)group }\end{array}$ \\
\hline \hline $\begin{array}{c}\text { Group 1 } \\
\text { control - ve }\end{array}$ & $11.30 \pm 0.26 \mathrm{a}$ & 101.79 & $3.20 \pm 0.13 \mathrm{~cd}$ & -34.69 \\
\hline $\begin{array}{c}\text { Group 2 } \\
\text { control + ve }\end{array}$ & $5.60 \pm 0.36 \mathrm{e}$ & 00.00 & $4.90 \pm 0.52 \mathrm{a}$ & 00.00 \\
\hline $\begin{array}{c}\text { Group 3 } \\
\text { 5\% Almond nut }\end{array}$ & $10.60 \pm 0.53 \mathrm{~b}$ & 89.29 & $3.50 \pm 0.34 \mathrm{bc}$ & -28.57 \\
\hline $\begin{array}{c}\text { Group 4 } \\
\text { Sambucus } \\
\text { herbs }\end{array}$ & $9.80 \pm 0.24 \mathrm{c}$ & 75.00 & $2.90 \pm 0.17 \mathrm{de}$ & -40.81 \\
\hline $\begin{array}{c}\text { Group 5 } \\
5 \% \text { Juniperus seeds }\end{array}$ & $7.00 \pm 0.35 \mathrm{~d}$ & 25 & $2.80 \pm 0.18 \mathrm{e}$ & -42.85 \\
\hline $\begin{array}{c}\text { Group 6 } \\
5 \% \text { Grapefruit } \\
\text { albedo }\end{array}$ & $9.90 \pm 0.36 \mathrm{e}$ & 76.79 & $3.00 \pm 0.43 \mathrm{de}$ & -38.77 \\
\hline $\begin{array}{c}\text { Group 7 } \\
5 \% \text { mixture }\end{array}$ & $11.20 \pm$ & 100.00 & $3.70 \pm 0.26 \mathrm{~b}$ & -24.48 \\
\hline LSD & 0.358 & & 0.315 & \\
\hline \hline
\end{tabular}

Values denote arithmetic means \pm standard deviation of the mean. Means with different letters ( $a, b, c$ and $d$ ) in the same column different significantly at $\mathrm{p} \leq 0.05$ using one way ANOVA test, while those with similar letters are nonsignificantdifferent.

\section{HISTOPATHOLOGICAL RESULTS.}

\section{Kidneys}

Microscopically, kidneys of rat from (control - group) revealed the noral histological structure of renal parenchyma (Photo.1). While mean, kidneys of rat from (control + group)showed vacuolations of epithelial lining renal tubules, presence of protein cast in the lumen of renal tubules (Photo..2), Atrophy of some glamerulars tufts (Photo..3) and peritubular inflammatory cells infiltration (Photo.4) .However, kidneys of rat from Almond nut 5\%showed no changes except slight congestion of capillary tufts (Photo..5). Moreover, kidneys of rat from Sambucus herbs 5\% revealed vacuolations of epithelial lining some renal tubules (Photo.6). Most examined sections from Juniperus seeds 5\%showed no histopathological changes (Photo..7,8), whereas, some sections from this group showed 
distension of bowmen's space (Photo..9) Some examined sections from Grapefruit albedo 5\% and mixture of all plants5\% revealed no histopatholigcal changes (Photo.. 11, 12).

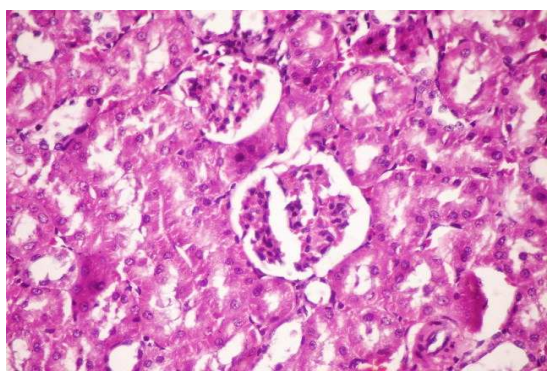

Photo (1): kidney of rats from (control group)showing the normal histoglical structure of renal parenchyma (Hand E X 400)

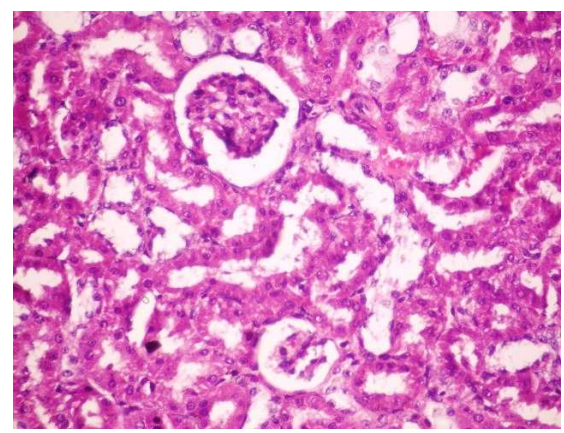

Photo (3): kidney of rats from (control + group) showing atroprly of some glomerular tubts $(\mathrm{H}$ and E X 400).

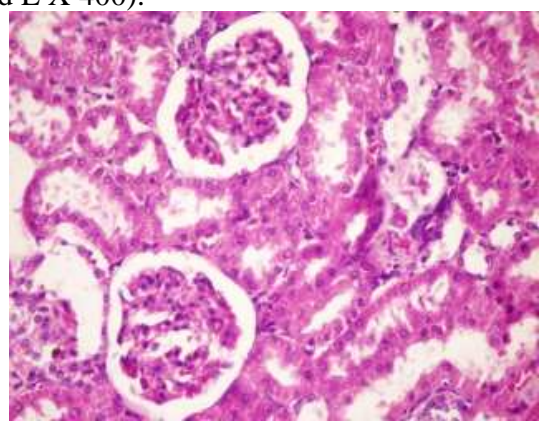

Photo (5): kidney of rats from Almond nut 5\% showing slight congestion of capillary tufts $(\mathrm{H}$ and $\mathrm{E} x$ 400).

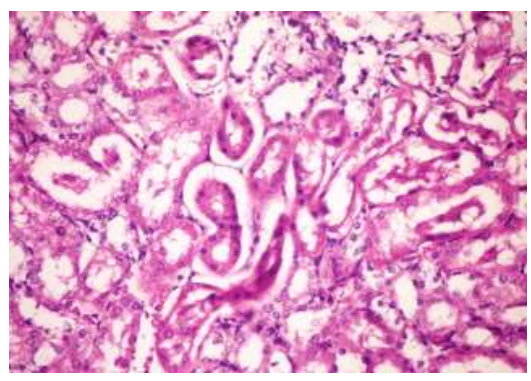

(2): Kidney of rat from group showing vacuolations of epithelial lining renal tubules and presence of protein cast in the lumen of renal tubules( $\mathrm{H}$ and $\mathrm{E} \mathrm{X} 400)$.

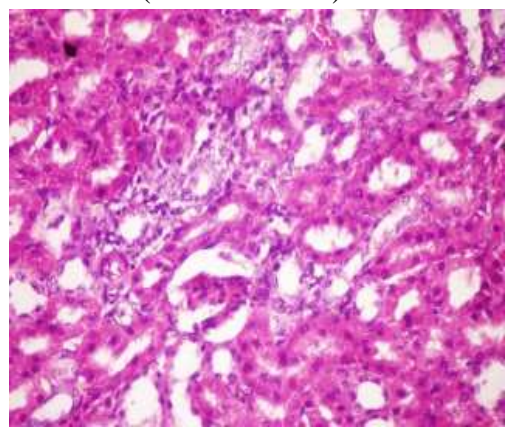

Photo (4): kidney of rats from (control + group) showing peritubular inflammatory cells infiltration (H and E X 400).

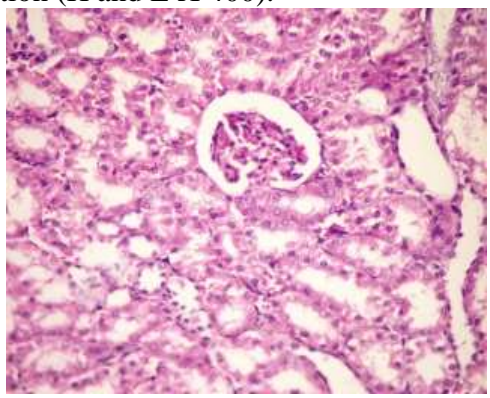

Photo (6): kidney of rats from Sambucus herbs $5 \%$ showing vacuolations of epithelial lining some renal tubules(H and E X400). 


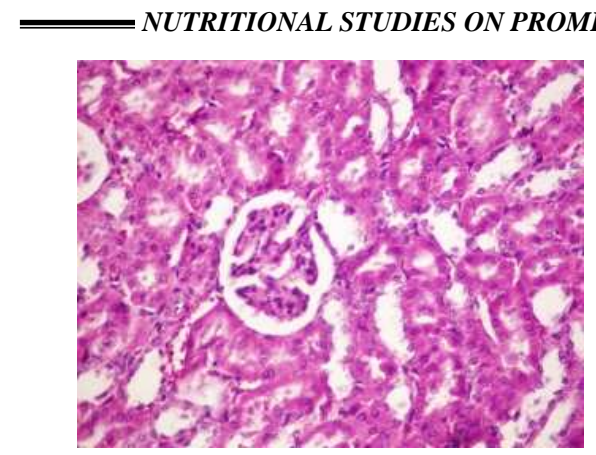

Photo (7): kidney of rats from group 22 showing no histopatholigical changes (H and E X 400)

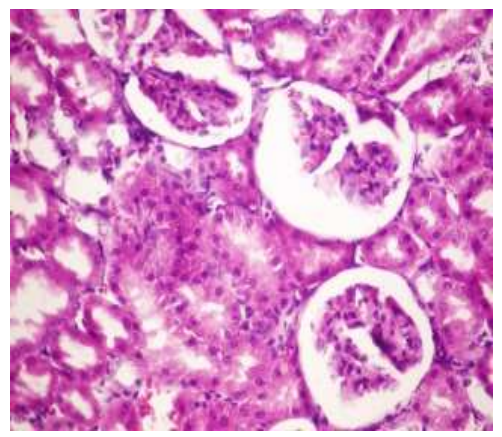

Photo (9): kidney of rats from Juniperus seeds $5 \%$ showing distension of Bowman's space $(\mathrm{H}$ and E X 400)

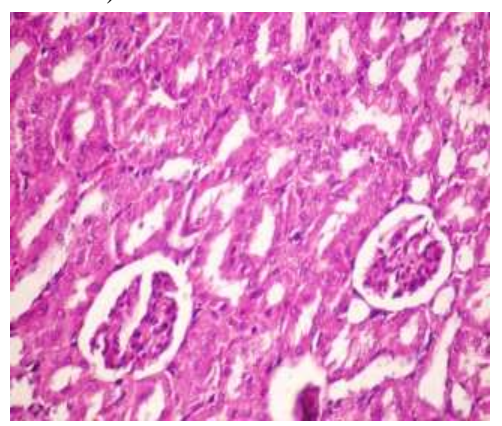

Photo (11): kidney of rats from Grapefruit albedo 5\% showing no histopathological changes (H and EX 400)

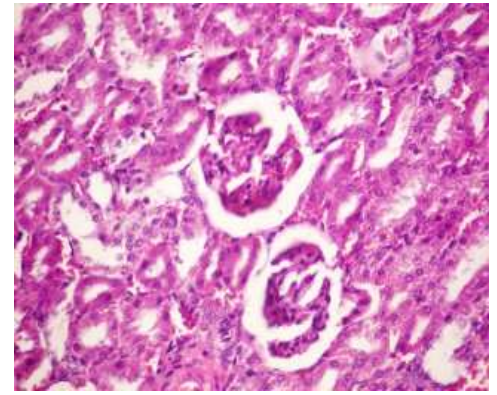

Photo (8): kidney of rats from group 22 showing no histopatholigical changes (H and E X 400)

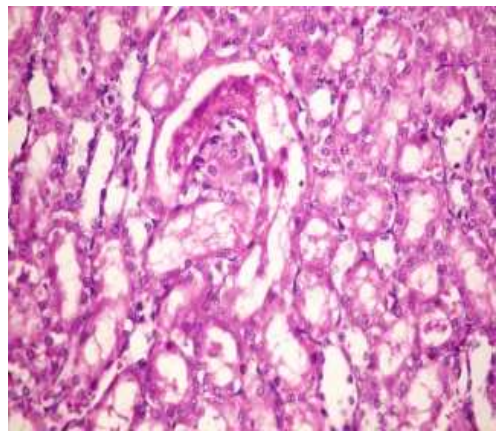

Photo (10): kidney of rats from Grapefruit albedo $5 \%$ showing eosinophilic protein cast in the lumen of renal tubules. (H and E X 400)

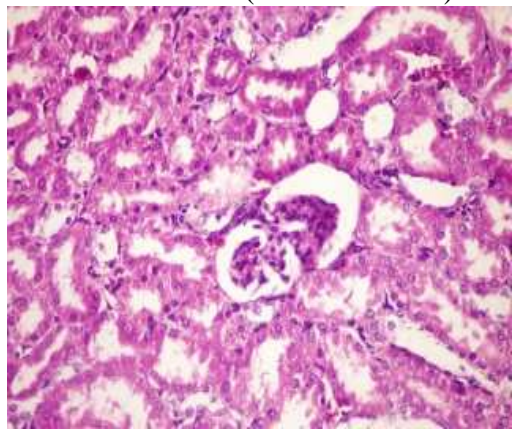

Photo (12): kidney of rats from mixture of all plants $5 \%$ showing no histopatholgical changes $(\mathrm{H}$ and E X 400).

\section{Liver}

Microscopically, liver of rat from (control -group) revealed the normal histological structure of hepatic lobule (Photo.1). While mean, liver of rat 
from (control + group) showed cytoplasmic vacuolization of hepatocytes (Photo. 2, 3). However, liver of rat from Almond nut 5\%

revealed local hepatic necrosis associated with inflammatory cells infiltration (Photo. 4) and kupffer cells activation (Photo.5). No histopatholigcal changes were noticed in liver of rat from Sambucus herbs 5\% (Photo.6). Examined sections from Juniperus seeds 5\% revealed kupffer cells activation and dilatation of hepatic sinusoids (Photo. 7, 8). However, liver of rat Grapefruit albedo 5\% showed

dilatation and cougestion of hepatic sinusoids (Photo. 9,10) and slight vacuolations of hepatocytes (Fig.12). Moreover, liver of rat from mixture of all Plants5\% revealed no changes except hydropic degeneration of some hepatocytes (Photo.11).

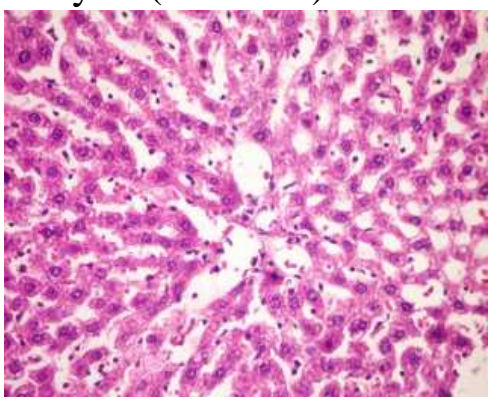

Photo (1): liver of rats from (control - group) showing the normal histological structure of hepatic lobule (H and E X 400).

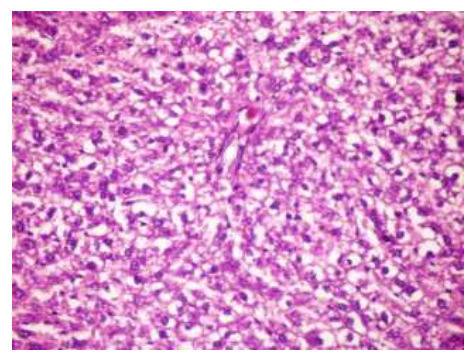

Photo (3): liver of rats from (control +group)showing cytoplasmic vacuolization of hepatocytes (H and E X 400).

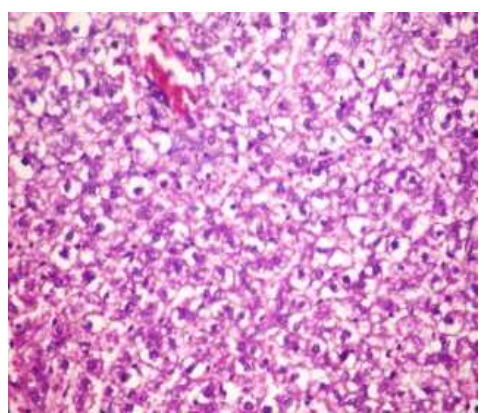

Photo (2): liver of rats from (control + group) showing cytoplasmic vacuolization of hepatocytes (H and E X 400).

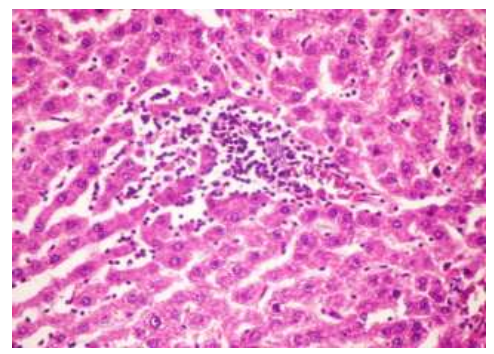

Photo (4): liver of rats from Almond nut $5 \%$ showing local hepatic mecrosis associated with hnflammatory cells infiltration( $\mathrm{H}$ and $\mathrm{E} \mathrm{X}$ 400) 


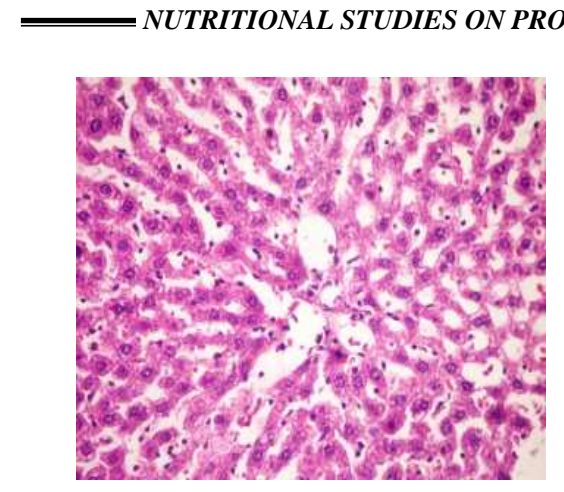

Photo (5): liver of rats from Almond nut 5\% showing kupffer cell activation (H and E X 400).

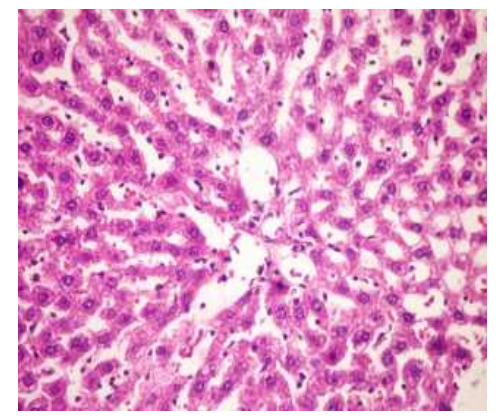

Photo (7): liver of rats from Juniperus seeds 5\% showing kupffer cells activation and dilatation of hepatic sinusoids (H and E X 400).

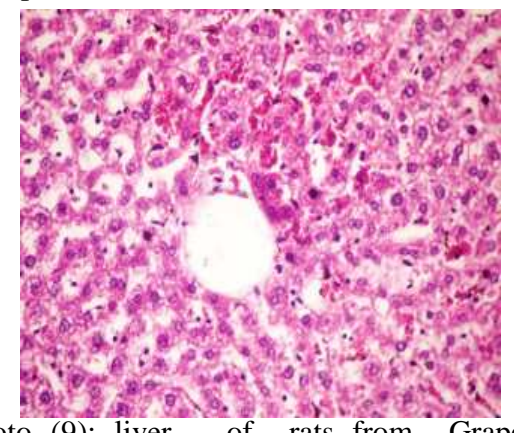

Photo (9): liver of rats from Grapefruit albedo 5\% kupffer cells activation and dilatation of hepatic sinusoids (H and E X 400).

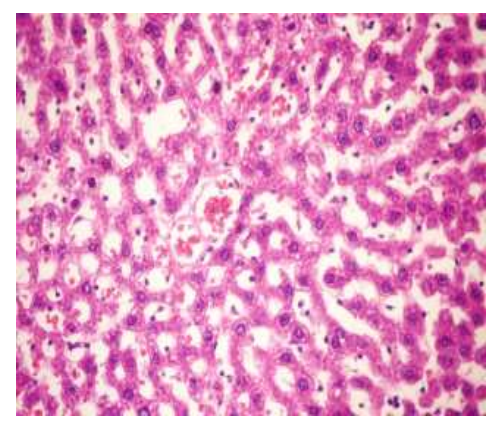

Photo (6): liver of rats from Sambucus herbs $5 \%$ showing no histopathological changes (H and E X 400).

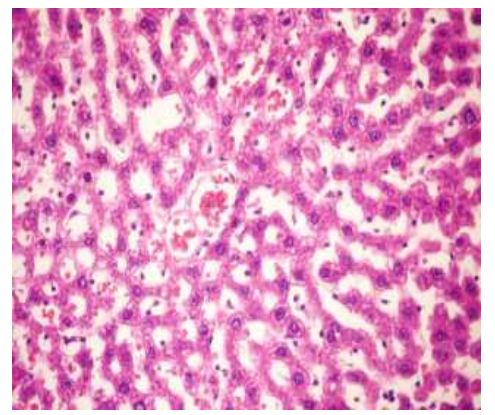

Photo (8): liver of rats from Juniperus seeds 5\% showing kupffer cells activation and dilatation of hepatic sinusoids (H and E X 400).

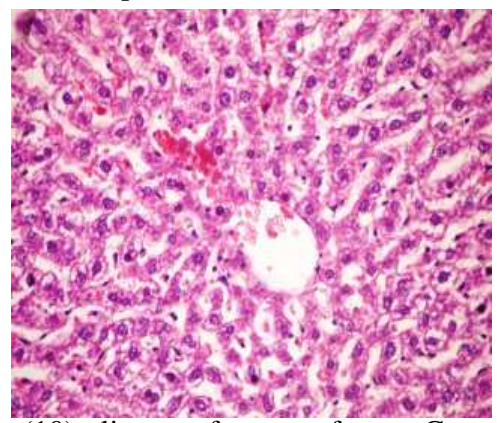

Photo (10): liver of rats from Grapefruit albedo 5\% showing slight vacuolations of hepatocytes and congestion of hepatic sinusoids (H and E X 400). 


\section{REFERENCES}

- Ali, A.N. (2011): "Blologcal Evaluatin Of Some Plants For Trentment And Supporting Nephropathy Rats Immunity" .M.SC. Thesis , Faculty of Home Economics, Minufiya U niversity.

- Allain,C.C. (1974):Cholesterol enzymatic colorimetric method .J.of Clin .Chem .,20:470.

- Anon,2012a: wikipedia org /wiki/ Almond.

- Anon,2012b: wikipedia org /wiki/ Sambucus.

- Anon,2012c: wikipedia org /wiki/ Juniper.

- Campbell,J.A.(1963):Methodology of protein evaluation.RAG. Nutr.Document R.10 Led 37.JUNE Meeting, New York.

- Chen ,c.y.; Lapsley,K.; Blumberg ,J. (2006): Nutrition and health perspective on almonds, issue .Journal of the Science of Food And Agriculture . 2245-220.

- Chapman, D. G.; Castilla, R, and Campbell, J.A. (1959):Evaluation of protein in food . I.A method for the deterinination of protein efficiency ratio. Can .J. Biochem.Phosiol.,37:679-686.

- Chrubasik ,C.; Maier ,T.; Dawid ,C.; Torda ,T.; Schieber, A.; Hofmann ,T.and Chrubasik, S.(2008): An observational study and quantification of the actives in a supplement with Sambucus nigra and Asparagus officinalis used for weight reduction. Phytother Res. 22(7):913-918.

- Ciocoiu ,M.; Mirón, A.; Mares, L.; Tutunaru, D.; Pohaci ,C.; Groza, M.and Badescu ,M.(2009): The effects of Sambucus nigra polyphenols on oxidative stress and metabolic disorders in experimental diabetes mellitus. J Physiol Biochem. 65(3):297-304.

- Daković-Svajcer, K.; Samojlik, I.; Rasković ,A.; Popović ,M.and Jakovljević ,V.(1999): The activity of liver oxidative enzymes after single and multiple grapefruit juice ingestion. Exp Toxicol Pathol. 51(4-5):304-308.

- Dow ,C.A .;Going ,S.B.; Chow, H.H.; Patil ,B.S. and Thomson ,C.A.(2012): The effects of daily consumption of grapefruit on body weight, lipids, and blood pressure in healthy, overweight adults. Metabolism.

- Druy, R.A.B. and Wallington ,E.A.(1980):Carlton's Histoloical Technique.5th Ed., Oxford University. 
- Dzharullaeva ,S.S.h.(2009): Phytochemical investigation of Juniper rufescens leaves and fruits]. Georgian Med News. (168):107-111

- El - Moselhy, S.M. (2007):" Influence Of Some Vegetables , Spices And Herbs On The Health Status Of Kidneys As Investigated Using The Experimental Animals ".M.SC. Thesis, Faculty of Home Economics, Minufiya U niversity.

- Fellers, P.J.; Nikdel ,S.and Lee, H.S . (1990): "Nutrient content and nutrition labeling of several processed Florida citrus juice products". J. Am. Diet. Assoc., 90 (8): 1079-1084.

- Fossatti and Prencipe (1980): Enzymatic colorimetric test of uric. J. of Clin. Chem.,28,227.

- Fnedewaid, W.T. (1972): Determination of HDL . Clin .Chem .,8:499.

- Fujioka,K.;Greenwa,y.F.; Sheard ,J. and Ying,Y.(2006): The effects of grapefruit on weight and insulin resistance: relationship to the metabolic syndrome. $\mathrm{J}$ Med Food. 9(1):49-54.

- Goldfarb,D.S and.Asplin, JR.(2001): Effect of grapefruit juice on urinary lithogenicity. J Urol. $2001 \mathrm{Jul} ; 166(1)$ :263-267.

- Gray, A.M.; Abdel-Wahab, Y.H.and Flatt, P.R.(2000): "The traditional plant treatment, Sambucus nigra (elder), exhibits insulin-like and insulin-releasing actions in vitro". J. Nutr. 130(1):15-20.

- Gordon ,T. and Amer ,M. (1977): Determination of HDL .J. Med., 62:707.

- Hegsted,D .;Mills. R. and perkins, E. (1941): Salt mixture. J.Biol. Chem ., 138:459.

- Henry,J.B.(1964): Colorimetric method of total protein . J. Of Clincal Chemistry, Harper, Row Publishers,New York .P.181.

- Henry,R.J.(1974): Clinical Chemistry Principles and Techniques. 2nd Ed ., Harper and Publishers, New York.

- Hönow ,R.; Laube, N.; Schneider, A.; Kessler, T. and Hesse, A.(2003): Influence of grapefruit-, orange- and apple-juice consumption on urinary variables and risk of crystallization. Br J Nutr. 90(2):295-300.

- Jaceldo-Siegl ,K.; Sabaté, J.; Batech, M.and Fraser, G.E.(2011): Influence of body mass index and serum lipids on the cholesterol-lowering effects of almonds in free-living individualsNutr Metab Cardiovasc Dis. 1:S7-13. 
- Jenkins, D.J.; Kendall ,C.W.; Marchie, A.; Josse, A.R.; Nguyen, T.H.; Faulkner, D.A.; Lapsley , K. Gand Singer ,W.(2008):

Effect of almonds on insulin secretion and insulin resistance innondiabetic hyperl ipidemic subjects a randomized controlled crossover trial. Metabolism. 57(7) : 882-887.

- Jenkins ,D.J.; Kendall, C.W.; Josse, A.R.; Salvatore, S.; Brighenti, F.; Augustin , L.S.; Ellis ,P.R.; Vidgen, E. and Rao, A.V.(2006): Almonds decrease postprandial glycemia, insulinemia, and oxidative damage in healthy individuals. J Nutr. 136(12):2987-2992.

- Ju ,J.B.; Kim, J.S.; Choi ,C.W.; Lee, H.K.; Oh ,T.K.and Kim ,S.C.(2008): Comparison between ethanolic and aqueous extracts from Chinese juniper berries for hypoglycaemic and hypolipidemic effects in alloxan-induced diabetic rats. J Ethnopharmacol. 115(1):110-115.

- Jenkins, D.J.; Kendall, C.W.; Marchie, A.; Parker, T.L.; Connelly, P.W.; Qian, W.; Haight ,J.S.; Faulkner, D.; Vidgen ， E.; Lapsley ,K. G. and Spiller ,G.A.(2002): Dose response of almonds on coronary heart disease risk factors: blood lipids, oxidized low-density lipoproteins, lipoprotein(a), homocysteine, and pulmonary nitric oxide: a randomized, controlled, crossover trial. Circulation. 106(11):1327-32.

- Kamil, A. and Chen, C.Y.(2012): Health benefits of almonds beyond cholesterol reduction. J Agric Food Chem.

- Khan, M.; Khan, A.U.; Rehman, N.U.; Zafar, M.A.; Hazrat, A.and Gilani, A.H.(2012): cardiovascular effects of Juniperus excelsa are mediated through multiple pathways. Clin. Exp. Hypertens. 34(3):209-16.

- Kim ,S.J.; Jung, J.Y.; Kim ,H.W. and Park ,T.(2008): Anti-obesity effects of Juniperus chinensis extract are associated with increased AMP-activated protein kinase expression and phosphorylation in the visceral adipose tissue of rats. Biol Pharm Bull. 31(7):1415-1421.

- Li ,S.C.; Liu ,Y.H.; Liu, J.F.; Chang ,W.H,; Chen ,C.M. and Chen, C.Y.(2011): Almond consumption improved glycemic control and lipid profiles in patients with type 2 diabetes mellitus. Metabolism. 60(4):474-479.

- Lee, R .D. and Nieman , D.C(1996):Nutritional Assessment . 2 nd Ed., Mosby , Missolun. USA 
- Lovejoy, J.C.; Most, M.M. ; Lefevre. M.; Greenway, F.L. and Rood, J.C.(2002): Effect of diets enriched in almonds on insulin action and serum lipids in adults with normal glucose tolerance or type 2 diabetes. Am J Clin Nutr. 76(5):10001006.

- Murkovic ,M.; Abuja, P.M.; Bergmann, A.R.; Zirngast ,A.;Adam ,U.; Winklh of er-Roob ,B.M. and Toplak, H. (2004): Effects of elderberry juice on fasting and postprandial serum lipids and low-density lipoprotein oxidation in healthy volunteers: a randomized, double-blind, placebo-controlled study. Eur J Clin Nutr. 58(2):244-249.

- Nakabayashi A.; Kitagawa Y.; Suwa .Y.; Akimoto K.(1995): a Tocopherol Enhances the Hypocholeserolemic Action of Sesames in Rats . Internat. J. Vit. Nutr. RES., 65(3):162-168.

- Orhan, N.; Aslan, M.; Pekcan ,M.; Orhan ,D.D.; Bedir, E.and Ergun ,F.(2012): Identification of hypoglycaemic compounds from berries of Juniperus oxycedrus subsp. oxycedrus through bioactivity guided isolation technique. $\mathbf{J}$ Ethnopharmacol. 139(1):110-118.

- Orhan, N.; Berkkan ,A.; Deliorman Orhan, D.; Aslan, M.;and Ergun F. (2011): Effects of Juniperus oxycedrus ssp. oxycedrus on tissue lipid peroxidation, trace elements $(\mathrm{Cu}, \mathrm{Zn}, \mathrm{Fe})$ and blood glucose levels in experimental diabetes. $\mathrm{J}$ Ethnopharmacol. 133(2):759-764.

- Patton, C. J. and Crouch,S.R (1977): Enzymatic determination of Urea . J.of Anal. Clin .Nutr.,76(3)560-568.

- Rincón ,A.M.; Vásquez ,A.M.and Padilla ,F.C.(2005): [Chemical composition and bioactive compounds of flour of orange (Citrus sinensis), tangerine (Citrus reticulata) and grapefruit (Citrus paradisi) peels cultivated in Venezuela]. Arch Latinoam Nutr. 55(3):305-310.

- Sheir ,M. I. (2009):"Biological And Technological Studies On Some Herbs That Affect On Kidney Function Disorder In Albino Rats, M. Sc. Thesis Faculty of Home

- Shen, J.; Niijima ,A.; Tanida ,M .;Horii ,Y.;Maeda, K. and Nagai, K.(2005): Olfactory stimulation with scent of grapefruit oil affects autonomic nerves, lipolysis and appetite in rats. Neurosci Lett. 380(3):289-294. 
- Snedecor ,G. W .and Cochran W.G . (1967):Statistical Methods .6 th Ed ., lowa State University press. Ames . Lowa .USA.

- Trinchieri, A.; Lizzano, R.; Bernardini, P .;Nicola .; M, Pozzoni, F.; Romano, A.L.;Serrago , M.P. and Confalanieri , S.(2002): Effect of acute load of grapefruit juice on urinary excretion of citrate and urinary risk factors for renal stone formation. Dig Liver Dis. 2:S160-163.

- Thefeld, W. (1974) : Determination of serum glutamic oxaloacetic transaminases (GOT) and glutamic pyruvic transaminase. Dt.Med.Wschr.,99342 .

- Tumen, I.; Süntar, I.; Keleş ,H.and Küpeli Akkol ,E.(2012): A therapeutic approach for wound healing by using essential oils of cupressus and juniperus species growing in Turkey. Evid Based Complement Alternat Med. 2012:728281.

- Vinson ,J.A.; Liang ,X.; Proch, J.; Hontz ,B.A.; Dancel ,J.and Sandone, N.(2002): Polyphenol antioxidants in citrus juices: in vitro and in vivo studies relevant to heart disease. Adv Exp Med Biol. 505:113-122.

- Wien, M.; Bleich ,D.; Raghuwanshi ,M.; Gould-Forgerite, S.; Gomes, J.; Monahan-Couch ,L.and Oda ,K.(2010): Almond consumption and cardiovascular risk factors in adults with prediabetes. J Am Coll Nutr. 29(3):189-197.

- Wien ,M.A.; Sabaté ,J.M.; Iklé ,D.N.; Cole, S. and EKandeel,F.R.(2003): Almond vs complex carbohydrates in a Weight Reduction program.Int.j. obesity 27(11):1365-1372.

- Zhu, S.X.; Liao, Q.F.; Wang ,X.S.; Qiu ,Y.W.; Yang, W.and Zhu, Q.(2008): [Research on active part of Sambucus chinensis against hepatitis mice induced by CCl4]. Zhong Yao Cai. 31(8):1216-1219. 


\section{دراسات تغذوية على نباتات}

\section{واعده لعلاج هرضى الكلى فى ذكور الفئران البيضاء}
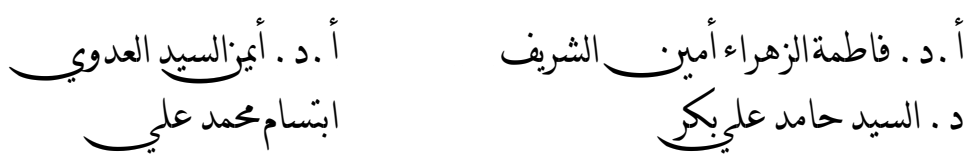

الملخص العربى

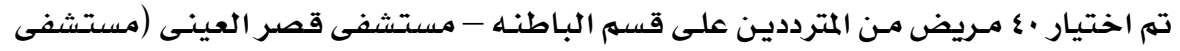

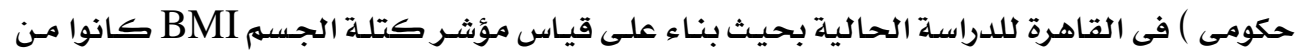

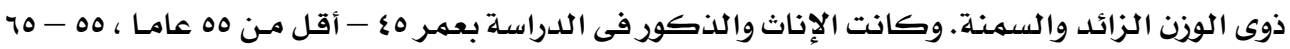

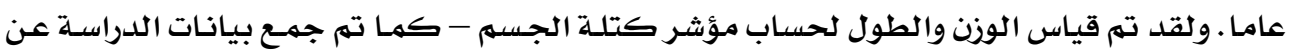

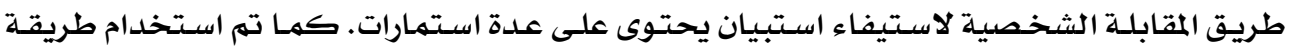

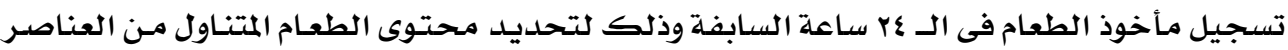

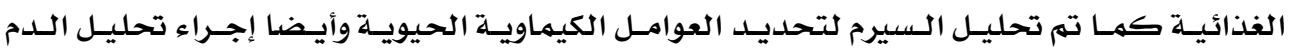
للحصول على الصورة الكاملـة.

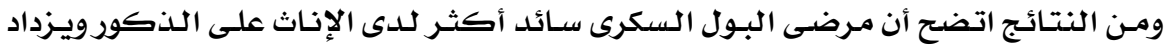

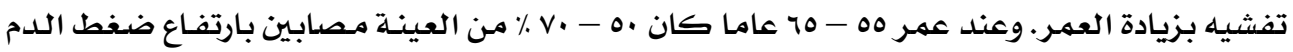

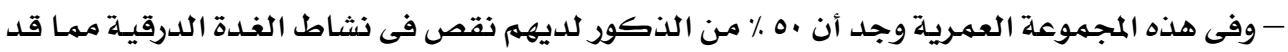

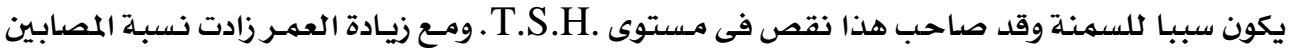

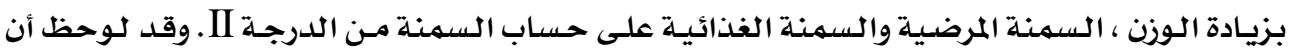
AMC ، AC ، TSF وقد اتضـح أن مأخوذ السعرات الكليـة والبروتين والدهن والكريوهيدرات كـان أكبر كثيرا

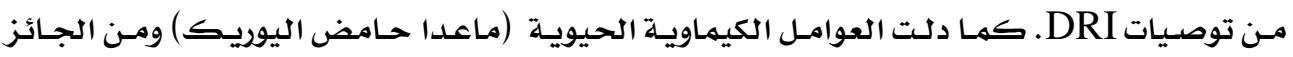
أيضا HDL على تدهور صحة أفراد العينة. هذا التدهور أيده أيضا التحليل لصورة الدم الدماعل الكاملة. 